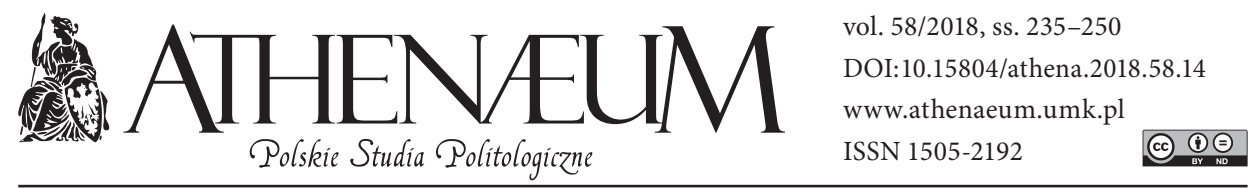

\title{
DYPLOMACJA WIETNAMSKA WOBEC STANÓW ZJEDNOCZONYCH NA PRZEŁOMIE LAT 70. I 80. XX W.
}

\author{
VIETNAMESE DIPLOMACY TOWARDS \\ THE UNITED STATES AT THE TURN \\ OF THE 1970S AND 1980S
}

Małgorzata Pietrasiak*

\begin{abstract}
ABSTRAKT
Po podpisaniu Porozumień Paryskich (27.01. 1973 r.), a następnie zlikwidowaniu reżimu Thieu (1975) i zjednoczeniu państwa (1976 r.) Wietnam podjął wysiłek dyplomatyczny w celu normalizacji stosunków wzajemnych. Prowadzone na ten temat rozmowy ostatecznie zakończyły się fiaskiem. Złożyło się na to wiele przyczyn. Konflikt między Zbigniewem Brzezińskim i Cyrusem Vancem nie sprzyjał efektywności rozmów. Zbigniew Brzeziński był przeciwnikiem jakiegokolwiek kompromisu w rozmowach $\mathrm{z}$ Wietnamem i uważał, że najpierw należy unormować stosunki z Chinami, a dopiero potem $z$ Wietnamem. Chiny w okresie napiętych stosunków z ZSRR, w czasie afgańskiej interwencji, mogły być sojusznikiem dla niektórych dyplomatycznych akcji.

Wietnam też zrobił kilka błędów. Błędem było wkroczenie wojsk do Kambodży, co spowodowało izolację Wietnamu i w konsekwencji uza-
\end{abstract}

After signing Paris agreements (January 27th, 1973) and the suppression of the Thieu regime (1975) and unification of the state (1976), Vietnam took the diplomatic efforts to the purpose of normalization of mutual relationships. Eventually, the conversations ended in a fiasco, for a number of reasons. Conflict among Zbigniew Brzeziński and Cyrus Vance did not support the effectiveness of conversations. Zbigniew Brzeziński was an opponent of any compromise in talks with Vietnam and thought that at first the US should normalize relationships with China and only then with Vietnam. At the time of tension with the USSR during the Afghan intervention, China could have been an ally for some diplomatic shares.

Vietnam also made a few mistakes. Vietnamese intervention in Cambodia was a big mistake. In consequence of this, Vietnam was isolated in the

* Uniwersytet Łódzki, Wydział Studiów Międzynarodowych i Politologicznych.

ORCID: https://orcid.org/0000-0002-4279-1483. 
leżnienie się od ZSRR. Polityka Wietnamu w tym okresie była mało elastyczna. Wietnam dążył do uzyskania rekompensaty za straty wojenne, co kwestionowali amerykańscy negocjatorzy, wychodząc z założenia, że siłowe przejęcie władzy zwalnia stronę amerykańską z tych zobowiązań. Wietnam wycofał się z żądań, zmodyfikował swoją pozycję i nawet przekazywał cenne informacje o MIA, ale administracja amerykańska uznała, że to za późno, odkładając na dwadzieścia lat wzajemne uznanie i nawiązanie stosunków dyplomatycznych.

Słowa kluczowe: dyplomacja wietnamska, polityka zagraniczna Stanów Zjednoczonych, wietnamsko-amerykańskie stosunki dwustronne, region Azji Południowo-Wschodniej world area and became dependent on the USSR. The politics of Vietnam in this period was not very flexible. Vietnam sought compensation for war losses, what was questioned by the American negotiators. They assumed that the military takeover exempts the US from these obligations. Vietnam decided to withdraw the requests, modified its position and even communicated valuable information about MIA, but the American acknowledged that it was too late, putting off the mutual recognition and the reference for twenty years establishing diplomatic relations.

Keywords: Vietnamese diplomacy, foreign policy of the United States, Vietnam-US bilateral relations, Southeast Asia region

Celem artykułu jest analiza relacji amerykańsko-wietnamskich po zakończeniu wojny indochińskiej i zjednoczeniu Wietnamu. Analiza została przeprowadzona głównie w oparciu o środowiskowy model badań, uwzględniający trzy podstawowe wartości: środowisko międzynarodowe, uczestników i ich działania. Ewolucja środowiska międzynarodowego i gra mocarstw determinowały działania zjednoczonego w 1976 r. państwa. Na tym tle rozpatrywany jest główny problem badawczy: jakie podejmowano działania, aby unormować relacje z USA i co było przeszkodą dla procesu normalizacji stosunków dwustronnych?

W połowie lat 70. dyplomatyczne wysiłki SRW doprowadziły do zainicjowania dialogu zmierzającego do nawiązania stosunków dyplomatycznych ze Stanami Zjednoczonymi. W artykule przeanalizowano te wszystkie czynniki, które ostatecznie odsunęły o dwadzieścia lat proces normalizacji stosunków dwustronnych między dwoma państwami po zakończeniu wojen indochińskich. Do nich zaliczono: zbyt twarde stanowisko wietnamskie, związane $\mathrm{z}$ odszkodowaniami wojennymi, nie dość empatyczne zachowanie związane z poszukiwaniem zaginionych i poległych żołnierzy amerykańskich i krytykę działań wietnamskich w Kambodży. Najważniejszą przeszkodą była jednak sytuacja międzynarodowa, zwłaszcza czynnik chiński, który w polityce amerykańskiej spowodował odłożenie spraw wietnamskich na korzyść uregulowania relacji z ChRL, wówczas skonfliktowaną z południowym sąsiadem. 


\section{SYTUACJA POLITYCZNA WIETNAMU PO PODPISANIU POROZUMIEŃ PARYSKICH}

Dnia 27 stycznia 1973 r. rządy Stanów Zjednoczonych, Demokratycznej Republiki Wietnamu, Tymczasowego Rewolucyjnego Rządu Wietnamu Południowego i Republiki Wietnamu podpisały w Paryżu układ o zaprzestaniu wojny i przywróceniu pokoju w Wietnamie. Wojna dla Ameryki skończyła się nie tylko klęską, ale i śmiercią 58 tys. Amerykanów, stratami w wysokości 150 mld USD wyrzuconych w bezsensowną wojnę oraz frustracją Amerykanów (Pike, s. 224). $\mathrm{Na}$ wiele lat Ameryka wycofała się z Azji Wschodniej i nie miała pomysłu na współpracę w nowej sytuacji.

W Rozdziale VIII Porozumień zatytułowanych: Stosunki między Stanami Zjednoczonymi i Demokratyczna Republikg Wietnamu zapisano: „Stany Zjednoczone przewidują, że Porozumienie będzie wprowadzone w okresie pojednania z Demokratyczną Republiką Wietnamu i wszystkimi narodami Indochin. W uzupełnieniu, nawiązując do tradycyjnej polityki, Stany Zjednoczone będą wspomagać leczenie ran wojennych i powojenną odbudowę Demokratycznej Republiki Wietnamu i całych Indochin" (Agreement on Ending the War and Restoring Peace in Vietnam).

Kwota nie została uściślona, ale 1 lutego 1973 r. prezydent Nixon w liście do premiera Pham Van Donga poinformował o woli przekazania w sumie na pomoc 4,75 mld USD. W liście oprócz sumy 3,3 mld USD, związanej z odszkodowaniami, wymieniona była kwota 1-1,5 mld USD na żywność i inne formy pomocy doraźnej (Text of Message From the President of the United States; „,The New York Times”, 22.05.1977). Drugi list, w którym prezydent potwierdza wolę przekazania zgodnie z Porozumieniami Paryskimi zadośćuczynienia finansowego, był skierowany do kongresmena Lestera Wolffa. Sprawę upubliczniono dopiero po aferze Watergate. Oferta nie przewidywała warunków politycznych, ale miała być zgodna ofertą przekazaną Wietnamczykom w czasie tajnych negocjacji, jakie prowadził Henry Kissinger.

Po podpisaniu Porozumień Paryskich sytuacja polityczna i międzynarodowa wokół Wietnamu powoli zaczęła się stabilizować. Umożliwiała ona wyjście Wietnamu z izolacji międzynarodowej. 7 lutego Demokratyczną Republikę Wietnamu uznała Kanada, następnie uczyniły to: Australia, Kamerun, Gwinea, Zambia, Austria, Tunezja, Republika Malgaska, Bangladesz, Islandia, Finlandia. 13 kwietnia 1973 r. między Francją a Wietnamem ogłoszono wznowienie stosunków dyplomatycznych na szczeblu ambasadorów. Zgodnie z układami 
Stany Zjednoczone rozpoczęły wycofywanie żołnierzy z Wietnamu. Najsłabszym punktem w procesie normalizacyjnym był brak porozumienia między Republiką Wietnamu a Tymczasowym Rządem Rewolucyjnym.

Przesuwały się również rozmowy ze Stanami Zjednoczonymi na temat rekompensaty za straty wojenne. W Sztokholmie w tej sprawie odbyła się konferencja międzynarodowa, która wezwała do ścisłego wypełniania Porozumień Paryskich.

Brak porozumienia między reżimem Thieu a komunistami spowodował wznowienie walk. Thieu liczył na wsparcie ze strony administracji amerykańskiej. O swoim poparciu zapewniał prezydent Nixon w czasie jedynego swojego spotkania z prezydentem Thieu w San Clement na początku kwietnia 1973 r. (Remarks of Welcome to President Nguyen Van Thieu). Kongres nie chciał jednak w dalszym ciągu wspierać południowowietnamskiego reżimu. W opinii amerykańskich kongresmenów i tak żadna suma nie była w stanie uratować Wietnamu Południowego („Time”, 21.04.1975). Ponadto wpływ na dodatkowe cięcia budżetowe miała afera Watergate i dymisja Nixona 9 sierpnia 1974 r.

Ostateczną decyzję całkowitego zlikwidowania reżimu Thieu w 1975 r.i zjednoczenia obu państw wietnamskich podjęto w czasie kolejnych posiedzeń Biura Politycznego KC PPW w grudniu 1974 r. i styczniu 1975 r. (Lich Su Dang Cong San Viet Nam, s. 218).

Stany Zjednoczone nie zaakceptowały siłowych rozwiązań w Wietnamie Południowym, co oznaczało dla zjednoczonego państwa utrudnienia dla normalizacji stosunków i uzyskania rekompensat. Dodatkowo utrzymanie równego dystansu wobec dwóch największych sojuszników ZSRR i Chin stawało się coraz trudniejsze, a przecież te dwa państwa były największymi dawcami pomocy gospodarczej. Zatem zadania, jakie postawiono przed dyplomacją wietnamską, polegały na przeciwdziałaniu ponownej interwencji amerykańskiej i uspokojeniu amerykańskiej opinii publicznej oraz wygraniu poparcia ze strony ZSRR i Chin. Nie było to zadanie łatwe, albowiem już wówczas uwidoczniły się kontrowersje w stosunkach z Chińską Republiką Ludową. W styczniu 1974 r. wojska chińskie zajęły wyspy Hoang Sa (Paracele), które Wietnam (oba rządy) uznawał za swoje suwerenne terytoria. $\mathrm{W}$ dodatku liczna powojenna migracja wietnamska była niechętna komunistom. W styczniu 1975 r. ruszyła ofensywa północnowietnamska. W połowie lutego prezydent Thieu wysłał do Waszyngtonu specjalnego emisariusza z prośbą o pomoc amerykańską, ale bez rezultatu (Vietnam Assesment Report by General Fred C. Weynand). Prezydent Gerald Ford w wykładzie wygłoszonym na Uniwersytecie w Nowym Orleanie stwierdził, iż wojna się 
skończyła i Stany Zjednoczone nie mogą dłużej pomagać Wietnamowi. Dnia 18 kwietnia wydał on rozkaz ewakuacji personelu amerykańskiego. Ostatnią próbą wypracowania kompromisu miało być spotkanie w Camp Dawid, które planowano na 29 kwietnia 1975. Tej samej nocy Sajgon został zdobyty i pokojowe próby z Camp Dawid straciły sens.

\section{PIERWSZE PRÓBY ROZMÓW AMERYKAŃSKO-WIETNAMSKICH}

Kolejny okres, w który zwycięski Wietnam wkroczył po trzydziestoletniej wojnie, wcale nie był łatwiejszy od tego, który minął. Nie był łatwiejszy zarówno z powodu sytuacji międzynarodowej, jak i wewnętrznej. Tę co prawda usprawiedliwić można zadaniami związanymi z procesem unifikacji. Przecież obie części rozwijały się jako odrębne organizmy mające nie tylko różne systemy polityczne i gospodarcze, ale również różne systemy wartości. Atmosfera międzynarodowa wokół Wietnamu pod koniec lat 70. coraz mniej sprzyjała stabilizacji, choć jeszcze w połowie lat 70. XX w. niewiele na to wskazywało. Wietnam wygrał wszakże z liderem świata zachodniego. To znacznie ograniczyło obecność militarną Ameryki w regionie Azji Południowo-Wschodniej. W dodatku afera Watergate i rezygnacja prezydenta Nixona znacznie osłabiła przywództwo amerykańskie i była symptomem kryzysu „amerykańskiego imperializmu”. To, co osłabiało Amerykę, wzmacniało Związek Radziecki, którego wpływy wzrosły. Koniec kolonialnego systemu Portugalii: Angola, Gwinea Portugalska, Mozambik poszerzał radziecką orbitę wpływów. Tego obawiały się Chiny i o tym rozmawiał Chou Enlaj z prezydentem Nixonem. Konflikt między ZSRR a Chinami wydawał się być nierozwiązywalny, a Wietnam zmuszony był do opowiedzenia się po którejś ze stron. $\mathrm{O}$ ile w czasie wojny Wietnam, z powodzeniem, potrafił wykorzystać tę rywalizację zgodnie $\mathrm{z}$ własnymi celami, tak w nowej sytuacji międzynarodowej sojusze wietnamsko-radziecki i wietnamsko-chiński, po wycofaniu się amerykańskich wojsk, wymagały redefinicji. W Wietnamie odżyły dawne antychińskie nastroje, co ułatwiało wybór. Zatem niemal natychmiast po zakończeniu wojny z Ameryką Wietnam stanął przed kolejnymi konfliktami, najpierw z Kampuczą rządzoną przez Czerwonych Khmerów, a potem z Chinami.

Cała ta skomplikowana sytuacja towarzyszyła wietnamskim staraniom o nawiązanie stosunków dyplomatycznych z USA. W połowie 1975 r. premier Pham Van Dong wezwał Waszyngton do normalizacji stosunków i obiecanej pomocy. Proponował on powołanie funduszu rekonstrukcyjnego. Dwa amery- 
kańskie banki, Bank of America oraz First National City Bank, zostały poproszone o zajęcie stanowiska w sprawie rozwoju handlu z Wietnamem. Dodatkowo kompanie naftowe zostały zaproszone do współpracy w zakresie poszukiwań i eksploracji ropy naftowej (Pike, 1987, s. 226).

Nie wszyscy chcieli z zobowiązania pomocy i współpracy się wywiązać. Henry Kissinger nawoływał do daleko idącej powściągliwości. Taki ton wypowiedzi przeważał zwłaszcza po upadku Sajgonu. To on był zdania, że działania armii wietnamskiej powinny skutkować izolacją Wietnamu. Rzeczywiście 16 maja 1975 r. administracja USA bez konsultacji z Kongresem nałożyła embargo handlowe na Wietnam Północny i Południowy oraz Kambodżę i Laos (Menétrey-Monchau, 2006, s. 24). Nałożenie embarga na Wietnam ostro skrytykował demokrata Jonathan Bingham, który kierował podkomitetem Kongresu ds. handlu i biznesu. Twierdził on, że embargo może przedłużyć okres wrogości we wzajemnych stosunkach, a jego efektywność, jak pokazuje przykład Kuby, może być niewielka (Menétrey-Monchau, 2006, s. 24-25).

Pewną nadzieję na odwrócenie nieprzyjaznej orientacji w relacjach z Wietnamem dał prezydent Ford, który po powrocie z wizyty do państw regionu, 7 grudnia, w czasie przemówienia na uniwersytecie w Honolulu ogłosił swoją nową doktrynę Pacyfiku. Podstawowe pięć zasad, na których owa doktryna się opierała, sprowadzały się do: umocnienia partnerstwa z Japonią, normalizacji stosunków z Chińską Republika Ludową, wzmocnienia bezpieczeństwa i stabilności w regionie Azji Południowo-Wschodniej i rozwiązywania istniejących konfliktów (Weatherbee, 2008, s. 261).

W styczniu 1976 r. prezydent Ford zdecydował się wysłać do Wietnamu misję, na czele której stanął kongresmen G.V. (Sonny) Montgomery. Wrażenia, jakie odnieśli amerykańscy emisariusze ze spotkań z oddelegowanymi do rozmów Wietnamczykami, były jak najlepsze (Memorandum of Conversation, January 26, 1976).

Od marca 1976 r. trwała wymiana korespondencji między amerykańskim sekretarzem Henry Kissingerem a wietnamskim ministrem spraw zagranicznych Nguyen Duy Trinhem. Nguyen Duy Trinh obiecywał pomoc w poszukiwaniu zaginionych Amerykanów i przypominał w zamian o odszkodowaniach wojennych. Strona amerykańska zaprzeczyła, iż ciąży na niej obowiązek pomocy w odbudowie Wietnamu, a podstawowym argumentem, jakim się posługiwała, był ten związany z łamaniem Postanowień Paryskich i odmową porozumienia z rządem Thieu. W czasie wspomnianej rozmowy Montgomerego z premierem Pham Van Dongiem ten pierwszy stwierdził, że: „Nie ma możliwości udzielenia 
pomocy ekonomicznej i w odbudowie zniszczeń" (Memorandum of Conversation, Washington, January 26, 1976).

W roku 1976 doszło do pewnych politycznych zmian w obu krajach, były one naturalną konsekwencją zachodzących tam procesów politycznych i nie miały większego wpływu na prowadzone rozmowy: 2 lipca 1976 r. proklamowano powstanie Socjalistycznej Republiki Wietnamu ze stolicą w Hanoi i tym samym formalnie nastąpiło zjednoczenie Wietnamu. Nowym prezydentem w dniu 2 listopada tego samego roku został wybrany Jimmy Carter.

W Departamencie Stanu powołano grupę roboczą ds. otwarcia ambasady i nawiązania stosunków z Wietnamem. Prezydent Jimmy Carter uzależnił proces normalizacji stosunków z SRW od efektywnej pomocy w poszukiwaniach zaginionych i poległych żołnierzy. W marcu 1977 r. w Wietnamie przebywała misja Leonarda Woodcocka. Misja dotyczyła przede wszystkim poszukiwań i identyfikacji ciał MIA, ale przesłaniem była normalizacja stosunków dwustronnych. Po powrocie Woodcock dzielił się swoimi jak najlepszymi wrażeniami z tej wizyty. Potwierdził, że wszyscy zostali bardzo ciepło przyjęci. Rząd SRW oświadczył, że pomoc nie jest warunkiem koniecznym procesu normalizacji, co zapowiadało korzystne rozstrzygnięcia i dobrą wolę obu stron („New York Times”24.03.1977). Wizyta odniosła pewien pozytywny skutek, gdyż do Stanów Zjednoczonych powróciła grupa 12 osób uznawanych dotąd za zaginionych, a jednocześnie Stany Zjednoczone złagodziły nieco embargo nałożone na handel z Wietnamem.

Sprzyjająca atmosfera umożliwiła kolejne etapy rozmów. Rozpoczęły się one w Paryżu w dniach 3-4 maja 1977 r. Na czele delegacji wietnamskiej stanął wiceminister spraw zagranicznych Phan Hien, a amerykańskiej - zastępca sekretarza stanu Richard Holbrooke. Holbrook zaproponował wzajemne uznanie bez warunków wstępnych. Nie łączył bezpośrednio kwestii MIA z nawiązaniem stosunków dyplomatycznych i nie podejmował kwestii odszkodowań, ale obiecywał odstąpienie od embarga zaraz po tym, jak zostaną ustanowione stosunki dyplomatyczne. Tymczasem Phan Hien dążył do wypełnienia obietnicy danej Pham Van Dongowi i przypominał o rekompensowaniu zniszczeń wojennych (Dommen, 2001, s. 971). W czasie konferencji prasowej Holbrook był powściągliwy i jedynie nadmienił o konstruktywnych rozmowach, ale Pham Hien przypomniał o amerykańskich zobowiązaniach finansowych.

Przyjazne gesty w relacjach wietnamsko-amerykańskich skutkowały jeszcze jednym ważnym wydarzeniem. W konsekwencji rozmów w czasie posiedzenia Rady Bezpieczeństwa w dniu 20 lipca USA cofnęły swoje weto i w drodze konsensusu przegłosowano rezolucję nr 413(1977) rekomendującą przyjęcie 
Socjalistycznej Republiki Wietnamu do ONZ („Yearbook of the United Nations”, 1977, s. 370). Wietnam wyszedł z izolacji dyplomatycznej, stał się pełnoprawnym członkiem kolejnej organizacji międzynarodowej. Członkiem Ruchu Państw Niezaangażowanych został w 1975 r. Rozmowy amerykańsko-wietnamskie były kontynuowane w 1977 r. Organizacja Narodów Zjednoczonych stała się dobrym kanałem tych kontaktów. W październiku w czasie sesji ONZ Holbrook spotkał się z wiceministrem spraw zagranicznych Nguyen Co Thachem (Schulzinger, s. 10).

Amerykanie stawiali trzy warunki rozmów: pokojowe stosunki z państwami ASEAN, gwarantujące stabilizację i bezpieczeństwo regionalne, co - jak było powiedziane -Wietnamczycy już zaczęli realizować, pomoc w poszukiwaniach zaginionych w akcji oraz odesłanie ciał żołnierzy amerykańskich, którzy zginęli w Wietnamie. Wietnamczycy z kolei podkreślali swój najważniejszy postulat: obiecaną przez Amerykanów zgodnie z 21 art. Porozumień Paryskich pomoc w rekonstrukcji Wietnamu, na dowód czego opublikowali list prezydenta Nixona do premiera Pham Van Donga, w którym obiecywał on pomoc w wysokości 3,3 mld USD w ciągu pięciu lat (Text of Message From the President of the United States). W tym czasie, jak już było powiedziane, Amerykanie ten postulat odrzucali.

\section{SYTUACJA MIĘDZYNARODOWA WIETNAMU PO INTERWENCJI W KAMBODŻY}

Rozmowy dwustronne, które rozpoczęto w połowie lat 70., były trudne, choć wydawało się, że istnieje pole do kompromisu. Sytuacja międzynarodowa ponownie się skomplikowała. Wycofanie się Amerykanów i zwycięstwo komunistów w Wietnamie spowodowało zmianę układu sił w całych Indochinach. Demokratyczna Republika Wietnamu miała koncepcję zorganizowania Półwyspu Indochińskiego w pełni niezależnego od ChRL, z daleko idącym podporządkowaniem sobie Kambodży i Laosu. W Laosie władzę przejęło ugrupowanie skupione wokół partyzantów z Pathet Lao, a w 1977 r. Wietnam i Laos podpisały Układ o przyjaźni i współpracy, w którym oba kraje odwoływały się do idei „stosunków specjalnych”1 (IV Zjazd Komunistycznej Partii Wietnamu s. 157).

1 W Uchwale, przyjętej przez IV Zjazd Komunistycznej Partii Wietnamu (spadkobierczyni PPW) obradujący w 1976 r., w części dotyczącej polityki zagranicznej, zapisano: „Ze wszech miar rozwijać specjalne stosunki między narodem wietnamskim i narodami Laosu i Kampuczy”. 
Najbardziej niepokojące informacje napływały z Kampuczy². 17 kwietnia 1975 r. całkowitą władzę w tym państwie przejęli Czerwoni Khmerzy. Wydawało się, że wspólne podstawy ideologiczne, będące podstawą działalności zarówno partii rządzącej w Wietnamie, jak i nowej ekipy w Phom Penh pozwolą na ścisłą współpracę. Czerwoni Khmerzy mieli jednak własne priorytety polityczne, a koncepcja „stosunków specjalnych" została przez nich odrzucona, chociaż do 1977 r. wyraźnie się jej nie sprzeciwiali i werbalnie ją popierali³ (Dossier, s. 66). Dla Wietnamu oznaczało to zachwianie wypracowanej koncepcji bezpieczeństwa, której podstawowym gwarantem miało być wycofanie się Ameryki z Wietnamu, a kolejnym ścisła współpraca indochińskich partnerów. W 1977 r. między sąsiadami rozpoczął się otwarty konflikt graniczny. Do końca 1977 r. Chiny starały się unikać jednoznacznego opowiedzenia się po którejś ze stron. Próbowały nawet, na początku 1977 r., nakłonić przywódców khmerskich do podjęcia rokowań z Wietnamem i złożyły propozycję mediacji w konflikcie. Tym niemniej obawy przed wzrostem znaczenia zjednoczonego Wietnamu były widoczne w polityce Pekinu, który tradycyjnie popierał Kampuczę wolną od obcych wpływów.

Chiny zaczęły wspomagać militarnie Kampuczę i dodatkowo poprawiły stosunki z sojusznikiem USA z okresu wojny - Tajlandią. Zostało to odebrane w Hanoi jako akty wrogie (Dossier, s. 66.). W styczniu 1978 r. Wietnam zaproponował wzajemne wycofanie wojsk na odległość 5 mil w głąb granicy oraz rozmowy. W maju 1978 r. Kampucza zgodziła się na rozmowy, które miały się rozpocząć w styczniu 1979 r., ale sąsiad zdecydował się na rozwiązania siłowe.

W Kampuczy zainstalowano 160 tys. wietnamskich wojsk. Na czele nowego rządu stanął prowietnamski Heng Samrin. Chiny zareagowały bardzo ostro w lutym zażądały wycofania się wietnamskich wojsk z terytorium Kampuczy, a wojska chińskie, aby „dać lekcje”, przekroczyły granice z Wietnamem.

Udział wojsk wietnamskich w operacji kambodżańskiej przyniósł ogromne straty finansowe, polityczne i moralne. Prawie połowa wydatków wietnamskiego budżetu przeznaczana była na ten cel. Zginęło 23 tys. Wietnamczyków, a 55 tys.

2 Nazwa państwa kilkakrotnie się zmieniała od Kambodży, po Demokratyczną Kampuczę w okresie rządów Czerwonych Khmerów, następnie Ludową Republikę Kampuczy. Obecnie oficjalna nazwa państwa to Królestwo Kambodży.

${ }^{3}$ W liście z 25 stycznia 1975 r. adresowanym do Le Duc Tho Pol Pot zadeklarował: „Wszechstronna pomoc okazana przez Was - Wietnamską Partię Pracujących oraz bratni naród wietnamski wydatnie przyczyniła się do naszych zwycięstw. Traktujemy ją jako wyraz wielkich szlachetnych uczuć solidarności i rewolucyjnego braterstwa”. 
uznano za zaginionych ${ }^{4}$ (SarDesai, 2009, s. 162). Ucierpiał wizerunek państwa na arenie międzynarodowej, mimo że reżim Czerwonych Khmerów był z całą pewnością zbrodniczym i nie cieszył się zaufaniem sąsiadów. Stany Zjednoczone przy poparciu sojuszników skutecznie zablokowały pożyczki z Międzynarodowego Funduszu Walutowego, zahamowany został proces normalizacji stosunków z USA i Japonią, odłożono wejście Wietnamu do ASEAN.

W tym czasie rozmowy Wietnamu ze Stanami Zjednoczonymi utknęły w martwym punkcie. Do istniejących problemów doszły kolejne - problem uchodźców wietnamskich -boat people oraz exodus Wietnamczyków chińskiego pochodzenia Hoa po zmianach własnościowych na Południu. Groźny, również w kontekście dzisiejszej sytuacji w regionie, okazał się spór z Chinami o wyspy Paracelskie i Spratly. Cała ta sekwencja wydarzeń i wreszcie oficjalne poparcie Czerwonych Khmerów przez Chiny spowodowała znaczne ochłodzenie wzajemnych relacji i zadecydowała ostatecznie o ściślejszym sojuszu Wietnamu ze Związkiem Radzieckim.

To, co udawało się Wietnamczykom przez długi okres wojny, czyli ignorowanie konfrontacji chińsko-radzieckiej i - co więcej - wyciąganie dla siebie możliwie jak największych korzyści, stało się niemożliwe po wojnie. Wietnam gospodarczo, ale i politycznie uzależniał się od ZSRR. Z raportu Departamentu Stanu wyraźnie wynika konstatacja, że sytuacja dla Wietnamu jest niekomfortowa i szuka on dróg, aby zmienić ten stan rzeczy (Department of Defense. The Annual Report s. 51-52).

Rok 1978 był szczególnie nieudany dla relacji wietnamsko-amerykańskich. USA współpracowały z państwami ASEAN i naciskały, aby potępiły one Wietnam za inwazję. W konsekwencji ta niebezpieczna sytuacja zachwiała budującą się delikatną równowagą w regionie i na wiele lat odwlekła proces normalizacji stosunków z USA, a w konsekwencji pozostawiła Wietnam w izolacji politycznej i gospodarczej.

Dodatkowo sytuacja wewnętrzna Wietnamu pogarszała się. W pierwszym okresie ludność podeszła do procesu zjednoczenia entuzjastycznie. Wyobrażano sobie, że wkrótce niemal automatycznie nastąpi poprawa ich poziomu życia. Przecież to wojna była przyczyną nieszczęść, większe były nakłady na cele militarne, teraz uwolnione środki mogły być przeznaczone na inne dziedziny gospo-

4 Brak jest oficjalnych wietnamskich danych dotyczących liczby poległych w czasie operacji żołnierzy Wietnamskich. Podobną do wskazanych w artykule liczbę podaje agencja BBC - ok. 30 tys. http://www.bbc.com/news/world-asia-29106034. 
darki. Tymczasem sytuacja nie tylko nie uległa poprawie, lecz wręcz przeciwnie - jak było powiedziane, systematycznie się pogarszała. Pod koniec lat 70. XX w. ludzie zaczęli okazywać apatię, tym bardziej że coraz większym strumieniem, mimo ograniczonych kontaktów Północ-Południe, zaczęły napływać informacje o wyższym poziomie życia na Południu. Wbrew oficjalnej propagandzie rozpowszechniła się „żółta kultura”, przede wszystkim wśród młodzieży. Jeszcze trudniejsza sytuacja była na Południu: niestabilna gospodarka prowadziła do napięć i zamieszek, nie starczało wyżywienia, królowało bezrobocie. Większość właścicieli kapitału uciekła za granicę, zamknięte zostało źródło dostaw surowców, nie funkcjonowała kolej, kwitł czarny handel i korupcja. Skomasowanie tych trudności nastąpiło pod koniec lat 70., kiedy na piętrzące się trudności natury wewnętrznej nałożył się nieprzyjazny klimat międzynarodowy, związany z wkroczeniem wojsk wietnamskich do Kampuczy. Swoje niezadowolenie okazywali również Rosjanie. Wietnamczycy byli oskarżani o to, że dużą część pomocy po prostu marnotrawią.

Podsumowując, do tych najgroźniejszych czynników destabilizujących sytuację w regionie zaliczyć należy dwa podstawowe: całkowite załamanie się wietnamskiej gospodarki oraz będący konsekwencją kryzysu politycznego we wzajemnych relacjach konflikt graniczny z Kampuczą. Z nich wypływały kolejne: problem boat people $e^{6}$; uzależnienie gospodarcze od Związku Radzieckiego i państw Europy Wschodniej; konflikt graniczny z Chińską Republiką Ludową i w konsekwencji zamrożenie stosunków dwustronnych; pogorszenie stosunków z państwami regionu Azji Południowo-Wschodniej i wreszcie zahamowanie procesu normalizacji stosunków ze Stanami Zjednoczonymi.

5 Pod pojęciem żółtej kultury rozumiano muzykę, piosenki, utwory współczesne charakterystyczne dla Zachodu, ale wykonywane przez Wietnamczyków i po wietnamsku.

6 Problem boat people pojawił się po raz pierwszy po ofensywie komunistycznej w Kambodży, Laosie i Wietnamie. Po ewakuacji Amerykanów ponad 130000 osób związanych z dawnym reżimem: urzędników, oficerów, przedsiębiorców zaczęło opuszczać Indochiny i najczęściej poprzez Morze Południowo-Chińskie, na niewielkich łódkach, przypływali do Hongkongu, Singapuru, Malezji. Urząd Wysokiego Komisarza d.s. Uchodźców ONZ otworzył swoje biuro w Laosie w październiku $1974 \mathrm{r}$. i oddział w Hanoi w czerwcu 1975 r., aby pomóc uchodźcom. Pierwszym zadaniem było zapewnienie środków na przeżycie. 


\section{FIASKO ROZMÓW ZE STANAMI ZJEDNOCZONYMI}

Jak było powiedziane, Wietnam dostrzegał niebezpieczeństwo pełnego uzależnienia się od ZSRR, Stany Zjednoczone mogły być pewną przeciwwagą w dobie pogarszających się coraz bardziej stosunków z Chinami. W lipcu 1978 r. Wietnam jeszcze raz zadeklarował wolę normalizacji stosunków ze Stanami Zjednoczonymi, bez warunków wstępnych. O ile doradcy z Departamnetu Stanu Cyrus Vance i Richard Holbrooke uznali nowe propozycje za całkiem korzystne i interesujące, o tyle doradca ds. bezpieczeństwa Zbigniew Brzeziński ostrzegał, że Wietnam jest azjatycką Kubą walczącą z Chinami i Kambodżą w imię hegemonistycznych ambicji ZSRR (SarDesai, 2009, s. 200-201). Wielokrotnie tłumaczył, dlaczego jego zdaniem, normalizację stosunków z Wietnamem należało odłożyć. Twierdził między innymi, że naprawa relacji z Wietnamem była nierozłącznie traktowana z procesem normalizacji z Chinami, a ponieważ wśród ekspertów znane były problemy chińsko-wietnamskie, należało określić priorytety i wydawało się, że nie da się obu spraw zrealizować jednocześnie. Normalizacja stosunków z Wietnamem, zdaniem Brzezińskiego, mogła odbić się negatywnie na relacjach z Chinami. Dlatego administracja amerykańska zdecydowała się ostatecznie odłożyć stosunki z Wietnamem i zająć się tylko Chinami.

W czasie wizyty studyjnej we wrześniu 2014 r. w Wietnamie przeprowadziłam konsultacje naukowe $\mathrm{z}$ profesorem Nguyen $\mathrm{Vu}$ Tungiem, profesorem Akademii Dyplomatycznej w Wietnamie, specjalistą zajmującym się stosunkami wietnamsko-amerykańskimi. W czasie rozmowy prof. Nguyen Vu Tung wyraźnie wskazywał, że prywatna wojna Brzezińskiego i Vance’a negatywnie wpłynęła na proces normalizacji z Wietnamem.

Kolejne pytanie z cytowanego wcześniej wywiadu ze Zbigniewem Brzezińskim dotyczyło efektów polityki amerykańskiej i pełnego uzależnienia się Wietnamu od ZSRR. Brzeziński powiedział, że nie ma to związku z postępowaniem Ameryki, ponieważ Wietnam już znajdował się w obozie sowieckim. Odnosząc się do tej odpowiedzi, uważam, że jest to teza trudno weryfikowalna. Wskazuje na to chronologia wydarzeń, determinacja związana z uporządkowaniem stosunków zwłaszcza z państwami regionu, co dawałoby pewną przestrzeń do samodzielności, ale i Stanami Zjednoczonymi, co z kolei otwierałoby drogę do normalizacji stosunków z innymi zachodnimi gospodarkami.

Brzeziński w sprawie procesu normalizacji jeszcze raz potwierdził, że dla USA ważniejsze były relacje z Chinami niż z Wietnamem, te zaś dla Ameryki były drugoplanowe. Dziennikarz, polemizując z odpowiedzią Brzezińskiego, stwierdził, że 
z dzisiejszej perspektywy, patrząc na rozwój wzajemnych kontaktów, wstrzymanie procesu normalizacji przyniosło pewne szkody, np. opóźniło poszukiwania zaginionych żołnierzy, nie załatwiło sprawy uchodźców. Brzeziński z taką opinią się nie zgadzał. Przyznał, że Wietnamczycy mają własne priorytety i je realizują, prowadzą własną politykę; jego zdaniem nienawiązanie stosunków z USA nic tu nie zmieniło. Brzeziński stwierdził, że nie ma sobie nic do zarzucenia, celowo nie chciał ustąpić w wielu sprawach Wietnamczykom. Gdyby to było możliwe bez żadnych ustępstw, stwierdził, to można było ten dialog prowadzić, ale „Wietnam to nie był dla USA interes" (Interview with Zbigniew Brzeziński, 1983).

Jednak prezydent Carter jeszcze we wrześniu brał pod uwagę inną decyzję wbrew stanowisku Brzezińskiego i „w zasadzie” zgodził się na normalizację stosunków od listopada 1978 r. Wydarzenia z 1978 r., podpisanie Układu o przyjaźni i współpracy z ZSRR w dniu 3 listopada, a chwilę później wprowadzenie wojsk wietnamskich do Kambodży i poparcie dla nowego pro wietnamskiego reżimu ostatecznie przekonały administrację amerykańską co do słuszności opinii Brzezińskiego, że rozpoczętego procesu normalizacji nie należy kontynuować. Te wydarzenia wstrzymały proces dochodzenia do porozumienia.

Ten krótki okres w różny sposób jest interpretowany; jedni, np. Gareth Porter wskazują, że Wietnam był zdeterminowany do normalizowania relacji z USA, czego dowodem było odłożenie podpisania porozumienia z ZSRR (SarDesai, 2009, s. 201). Przychylam się do tej opinii - multilateralizacja partnerów w całym długim procesie odzyskiwania niepodległości przemawia za tym tradycyjnym modelem wietnamskiej dyplomacji. Uczeni wietnamscy tłumaczyli załamanie się negocjacji w inny sposób. Na ten temat autorce książki udało się porozmawiać z cytowanym już ekspertem Akademii Dyplomatycznej Wietnamu, prof. Nguyen Vu Tungiem. Jego zdaniem przeważyły interesy amerykańskie wobec silniejszego wietnamskiego oponenta - Chin. Zarysowała się możliwość porozumienia z Chinami i normalizacji stosunków, co zresztą się stało w styczniu 1979 r. Wola pozyskania sojusznika $\mathrm{w}$ trwającym wciąż zimnowojennym wyścigu zbrojeń z ZSRR przeważyła na korzyść Chin. Wietnam nie był rozpatrywany jako podmiot ważny dla interesów amerykańskich, lecz był postrzegany w szerszym kontekście międzynarodowym - jako „pionek na szachownicy”, posługując się metaforą Zbigniewa Brzezińskiego. Pamiętać należy, że Ameryka zmęczona była już wojną i samym tematem wietnamskim, wycofała się przecież z Indochin. Profesor Nguyen Vu Tung dodatkowo stwierdził, że i po stronie wietnamskiej na samym wstępie rozmów niepotrzebnie sprawa odszkodowań była stawiana jako warunek rozmów. 
Kyle Tadman w swoim artykule Amerykańska prowokacja: polityka zagraniczna USA w czasie sowiecko-afgańskiej wojny (Tadman, 2013, s. 17) przypomina jeszcze inny kontekst międzynarodowy tych wydarzeń - interwencja ZSRR w Afganistanie, niepokój związany z rozszerzaniem wpływów sowieckich na państwa azjatyckie, a nawet te będące tradycyjnie związane z USA w Ameryce Łacińskiej. Doktryna prezydenta Cartera opierała się na przeświadczeniu, że należy wszelkimi siłami powstrzymywać rosnącą militarną pozycję ZSRR (Tadman, 2013, s. 26).

Kolejne wydarzenia, w tym między innymi „lekcja”, jaką Chińczycy dali Wietnamowi w lutym 1979 r., jedynie wpływy rosyjskie umocniła, koalicja państw krytykujących obecność wojsk wietnamskich w Kambodży połączyła niedawnych przeciwników politycznych: państwa ASEAN, Chiny, USA, Japonię i państwa zachodnie, w tym nawet skandynawskie, które do niedawna wyrażały wsparcie dla proniepodległościowej walki wietnamskiej.

W latach 80. rząd wietnamski starał się ponownie stworzyć sprzyjający klimat dla rozmów, włączając się efektywnie w poszukiwania, ale dopiero nowe wewnętrzne liberalne procesy reformatorskie drugiej połowy lat 80 . XX w. oraz przeorientowanie polityki wietnamskiej w kierunku większej otwartości i wsparcie procesu reform rzeczywistą dywersyfikacją partnerów zmieniły nastawienie Ameryki. Sprzyjającą okolicznością był świeży powiew „pozimnowojennego wiatru”. Jak było pokazane w artykule, realizacja wietnamskich planów ściśle związana była z sytuacją międzynarodową.

\section{PODSUMOWANIE}

Pomimo amerykańskiej krytyki siłowego przejęcia władzy przez komunistów i zjednoczenia państwa na warunkach północnowietnamskich, w drugiej połowie lat 70. XX w. była szansa na unormowanie wzajemnych relacji. Rozmowy na ten temat trwały, ale ostatecznie do uregulowania dwustronnych stosunków nie doszło. Złożyło się na to wiele przyczyn. Konflikt między Zbigniewem Brzezińskim i Cyrusem Vancem nie sprzyjał efektywności rozmów. Niezależnie od tego obaj doradcy uważali, że ważniejsze są relacje z Chinami. Stosunki USA-Wietnam nie były rozpatrywane indywidualnie, a w szerszym międzynarodowym kontekście. Zwłaszcza Zbigniew Brzeziński był przeciwnikiem jakiegokolwiek kompromisu w rozmowach z Wietnamem i uważał, że najpierw należy unormować stosunki z Chinami, a dopiero potem Wietnamem. Chiny 
w okresie napiętych stosunków z ZSRR w czasie afgańskiej interwencji mogły być sojusznikiem dla niektórych dyplomatycznych akcji.

Wietnam też zrobił kilka błędów. Nie potrafił utrzymać równego dystansu ze swoimi zantagonizowanymi sojusznikami, lecz zwrócił się ku Rosji. Miał ponadto problem z Kambodżą i brak stosunków z ASEAN. Wkroczenie wojsk do Kambodży było największym błędem tego okresu. Polityka Wietnamu w tym okresie była mało elastyczna. Wietnam wystawił rachunek 3,25 mld USD za szkody wojenne i negocjował twardo. Dla amerykańskich negocjatorów takie stanowisko było nie do przyjęcia.

Wietnam wycofał się z żądań, zmodyfikował swoją pozycję i nawet przekazywał cenne informacje o MIA, ale administracja amerykańska uznała, że to za późno. Stany Zjednoczone wysyłały niejednoznaczne sygnały. Z jednej strony USA nie zastosowały veta w Radzie Bezpieczeństwa i Wietnam stał się członkiem ONZ, z drugiej Izba Reprezentantów zabroniła jakiejkolwiek pomocy, co bardzo drażniło skorych do kompromisu Wietnamczyków.

\section{BibLIOGRAFIA:}

(1973). Agreement on Ending the War and Restoring Peace in Vietnam, signed in Paris and entered into force. Pobrane $\mathrm{z}$ : https://www.mtholyoke.edu/acad/intrel/vietnam/ treaty.htm.

(1973). Remarks of Welcome to President Nguyen Van Thieu of the Republic of Vietnam at San Clemente, California. Pobrane z: http://www.presidency.ucsb.edu/ws/?pid=3789. (1975). Seeking the Last Exist from Vietnam. Time.

(1975). Vietnam Assesment Report by General Fred C. Weynand. Pobrane z: http://www. generalhieu.com/weyand-2.htm.

(1976). Memorandum of Conversation, Washington. Pobrane z: https://www.fordlibrarymuseum.gov/library/document/0314/1553347.pdf.

(1977). Text of Message from the President of the United States to the Prime Minister of the Democratic Republic of Vietnam. Department of State Bulletin, 76(1971-1983), 674.

(1980). IV Zjazd Komunistycznej Partii Wietnamu. Podstawowe dokumenty, Książka $i$ Wiedza. Warszawa.

(1987) Lich Su Dang Cong San Viet Nam (Tłum: Historia Komunistycznej Partii Wietnamu), Nha Xuat Ban Su That. Hanoi.

„The New York Times”, 22.051977.

„Yearbook of the United Nations", vol. 31, 1977.

Department of Defense. The Annual Report of Fiscal Year 1980. Pobrane z: http:// history.defense.gov/Portals/70/Documents/annual_reports/1980_DoD_AR.pdf? ver $=2014-06-24-150830-927$. 
Dommen, A. J. (2001). The Indochinese Experience of the French and the Americans: Nationalism and Communism in Cambodia, Laos, and Vietnam. Indiana University Press.

Interview with Zbigniew Brzeziński. Pobrane z: http://openvault.wgbh.org/catalog/ vietnam-fclf9b-interview-with-zbigniew-brzezinski-1983.

Kampuchea Dossier, vol. I, Hanoi 1978.

Menétrey-Monchau, C. (2006). American-Vietnamese Relations in the Wake of War: Diplomacy After the Capture the Saigon 19751979. London: McFarland.

Pike, D. (1987). Vietnam and the Soviet Union. Anatomy of an Alliance. London: Westview Press.

Robert, D. Schulzinger (2008). A Time for Peace: The Legacy of the Vietnam War. Oxford University Press.

SarDesai, D. R. (2009). Vietnam Past and Present. Los Angeles: University of California. Tadman K. (2013). An American Provocation: U.S. Foreign Policy during the Soviet Afghanistan War. Pobrane z: http://www.wiu.edu/cas/history/wihr/pdfs/Tadman-AnAmericanProvocationVol5.pdf.

Weatherbee, D. E. (2008). Historical Dictionary of United States-Southeast Asia Relations. Scarecrow Press. 